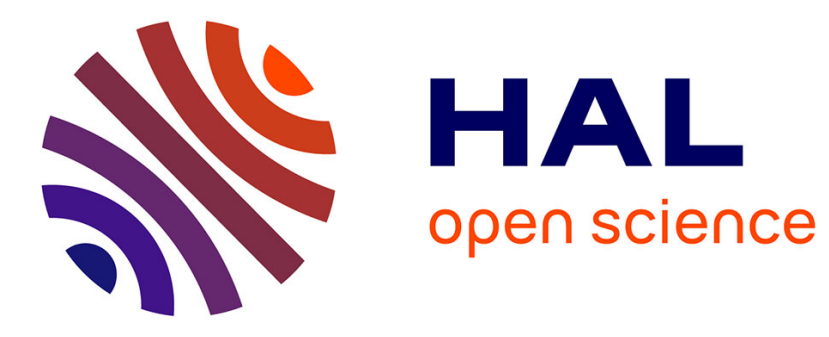

\title{
FOLLOWING THE NEW SILK ROAD BETWEEN YIWU AND CAIRO
}

\author{
Olivier Pliez
}

\section{To cite this version:}

Olivier Pliez. FOLLOWING THE NEW SILK ROAD BETWEEN YIWU AND CAIRO: A proposed method for understanding the inconspicuous sites of grassroots globalization. Mathews, G., Ribeiro, G. L., \& Vega, C. A. (Eds.). (2012). Globalization from below: the world's other economy, Routledge, p. 19-35, 2012, 978-0415535090. 10.4324/9780203106006 . hal-01441674

\section{HAL Id: hal-01441674 https://hal.science/hal-01441674}

Submitted on 20 Jan 2017

HAL is a multi-disciplinary open access archive for the deposit and dissemination of scientific research documents, whether they are published or not. The documents may come from teaching and research institutions in France or abroad, or from public or private research centers.
L'archive ouverte pluridisciplinaire HAL, est destinée au dépôt et à la diffusion de documents scientifiques de niveau recherche, publiés ou non, émanant des établissements d'enseignement et de recherche français ou étrangers, des laboratoires publics ou privés. 
Pliez O., 2012, "Following a silk road between Yiwu (China) and Cairo (Egypt). A proposed method for understanding the inconspicuous sites of grassroots globalization » in G. Mathews, G. L. Ribeiro et C. A. Vega (ed.) Economic Globalization from Below, p. 19-35

\section{FOLLOWING THE NEW SILK ROAD BETWEEN YIWU AND CAIRO}

\section{Olivier Pliez}

Geographer. Senior researcher at CNRS, Toulouse, France

\section{Introduction: multi-sited ethnography}

What link can be established between Tripoli, capital of the former rogue state of Libya, the small Egyptian border town of Salloum, inhabited by Bedouins, the Egyptian metropolis of Cairo, and Yiwu, a market city three hours' drive from Shanghai? At first glance, the question may seem like a guessing game, but in fact it leads geographers, anthropologists, and other social scientists to face the increasing difficulty of working out the unexpected and often invisible connections between locations along the routes of "globalization from below." Appadurai (2000: 3) proposed the term "grassroots globalization" to characterize social forms relying "on strategies, visions, and horizons for globalization on behalf of the poor," but I will opt for the different proposition of Ribeiro (2009: 298), defining this form of globalization as a "globalization from below' that is more linked to globalization's economic aspects than to its political ones." This is a way, according to Ribeiro, "to shed light on the hidden side of globalization's political economy, the one in which nation states' normative and repressive roles are $[\ldots]$ bypassed in the economic sphere." This is the "globalization from below" that this chapter will explore.

This chapter is based on a field investigation notebook kept between 2004 and 2009. Its intention is to highlight a key transnational trading route, one celebrated as the revival of the Silk Road (Molavi 2007; see also Stuttard 2000; Broadman 2007; Simpfendorfer 2009). The chapter seeks to show how places in the Middle East and North Africa (MENA) and China - industrial districts, ports, streets, or marketplaces - are linked together by actors working at different levels, dealing in more or less difficult geopolitical contexts to supply the market for consumption among the poor in Egypt and neighboring countries. This trading route forms a whole because of freight traffic and movements of people based on a logic which is barely perceptible on a local level, but which remains fundamental to the functioning of some very large networks of trade. Indeed, social scientists are facing the need to redefine continuities between spaces of production, negotiation and consumption "from below" in a globalized context.

"Strategies of quite literally following connections, associations, and putative relationships are [ ... ] at the very heart of designing multi-sited ethnographic research" (Marcus 1995: 97). Let's take this ethnographer's methodological proposals literally: he invites us to follow both goods and people, in order to grasp the scales and discontinuity of processes that can be observed in a precise place, while at the same time spread over different sites. Such a program is undeniably useful, even if we cannot neglect some serious critics. The sociologist Michael Burawoy is particularly persuasive when he declares that "by the end of its cultural turn, anthropology has lost its distinctive identity, having [ ... ] sacrificed the idea of intensively studying a 'site' [ ... ]. Bouncing from site to site, anthropologists easily substitute anecdotes and vignettes for serious field work, reproducing the cultural syncretism and hybridity of the peoples they observe" (Burawoy 2003: 674). Burawoy is not entirely wrong, but is to some extent depicting a caricature: to place under suspicion each researcher trying to follow goods, people or a road is absurd. Is the strategy of "revisits" to sites advocated by Burawoy an antidote against the temptation of superficiality inherent in practicing multi-sited analysis? I don't think so. I consider that these methods are not antithetical but complementary strategies to be used in the difficult task of gaining a precise idea (generally without much statistical data, since it can be extremely difficult to gather) of transnational activities along the routes of globalization from below.

Therefore, I strive in this chapter to develop a multi-sited analysis by following the movement of garments and 
small commodities made in Yiwu, China (Pliez 2007), labeled the world largest wholesale market of small commodities, then transported through a mix of licit and illicit practices to Egypt, the largest consumption market of the Arab world, either directly or via the Libyan port of Tripoli ${ }^{1} .1 \mathrm{I}$ focus on blue jeans in this investigation because it is the product most visible in the warehouses and markets of Libya and Egypt and worn by urban Egyptian teenagers. However, instead of dealing with this issue through the flow of goods, I instead analyze in this chapter the anchoring points between these flows (Craig 2002), the interactions between them, and the reshaped spatial scales which result from them. The routes of globalization from below are irregular and their anchoring points - borders, malls, marketplaces, and ports - vary depending on social, economic, and geopolitical contexts. These anchoring points are of interest to social scientists studying the spatial dynamics of global trade processes because the routes change more rapidly than the places they link. By identifying and mapping spaces related to transnational activities, at least the tip of the iceberg comprising the routes of economic globalization from below can be apprehended.

\section{Egypt: a market of $\mathbf{4 0}$ million consumers for Chinese products}

Egypt joined the World Trade Organization (WTO) from its inception in 1995, officially becoming a "star pupil" of the world agenda of trade liberalization. This had two essential consequences: first, the economic opening of the country rendered the existing tax-free areas null and void, and they were gradually dismantled; and second, Egypt's traditional business partners were to some extent supplanted. China soon took a dominant position and has been ranked third among Egypt's business partners in 2009 (with 7.1 percent of Egyptian foreign trade), behind the European Union (32.7 percent) and the United States (9.4 percent), with a commercial surplus of 3.84 billion euros (approx. 5.04 billion in US dollars) (Trade Egypt 2010).

These global statistics do not reveal the array of different kinds of products, as well as the practices of agents targeting one or another social level of consumption. It is difficult to distinguish between the importations of small or medium transnational agents and those of bigger firms. The issue of textile imports, for example, is not only particularly sensitive for the Egyptian clothing industry, whose workforce is characterized by oversupply and low productivity, but is also sensitive to the WTO schedule, which led to the abolition of quotas and tariffs on textiles between 2002 and 2004. Egypt feared the effects of such an opening and protected its textile industry from Chinese imports by putting technical obstacles in the way of these imports. But these protectionist measures, and the poor quality of local production, did not satisfy many Egyptian buyers, particularly those who were more modest in income; they tended to turn to China-made products.

The wealthiest, comprising about 3.5 million consumers, have been buying quality products from Europe or North America for decades. In the last twenty years, Middle Eastern centers such as Dubai, Istanbul and Beirut have been competing for this market, and are now themselves in competition with the luxurious commercial malls that are growing in number in central Cairo and its luxury suburbs, where gated communities have mushroomed (Zakaria 2006). The middle class, around 15 million people, shop for clothes and small commodities in the downtown Cairo area of Talaat Harb and in a few residential districts, as well as in other main Egyptian cities such as Alexandria. Aside from the above, an estimated 40 million people-leaving out the 20 percent of Egyptians living under living wage in 2005-comprise the enormous consumer market for cheap clothes, where Asian products, earlier manufactured in Thailand and Indonesia, and now in China, have replaced low-quality garments made in Egypt.

During the 1970s, both modest and wealthy Egyptians flocked to the port area of Port Said (Bruyas 2007) to buy imported duty-free goods often unavailable in the rest of the country. During this period, the Egyptian president, Anwar El Sadat, was attempting the first steps of economic opening, called the Infitah in Arabic. In the checkout lanes of the free zone, Port Saïd's shoppers mixed with dozens of traders and smugglers, who carried clothing and electronic products through customs in an unceasing shuttle. The demand was such that some Palestinian intermediaries offered clothes from Istanbul at lower prices than the ones imported through Port Saïd. The name has remained: one of the main wholesale clothing markets of Cairo, Jawhary, is also called the "Gaza Souk". Later, the importance of Port Saïd as a gateway for imports into Egypt gradually declined, and supply routes

\footnotetext{
${ }^{1}$ I investigated the cities of Tripoli (2003, 2005), Salloum (2005-2007), Cairo (2005-2007) and Yiwu (2006, 2009) for this chapter. I have also investigated marketplaces in Algeria (2000), the Libyan Sahara (1998, 2003) and Khartoum $(2004,2005)$, which are similarly wellconnected with the Gulf States - especially Dubai — and East Asia, although I do not discuss them in this chapter.
} 
became diversified and progressively globalized during the 1990s.

Paradoxically, legislation helped create the smuggling of imported garments during this period of strong state control of international trade. In Egypt customs duties were paid on imported material by the manufacturer, and provided that the final product was re-exported within one year, the manufacturer had the right to reclaim the already-paid duties in full. One estimate is that about US $\$ 300,000,000$ worth of jeans coming from China were brought annually into Egypt and then, after being relabelled, were re-exported as final products made in Egypt to the USA, a practice made particularly profitable because of this law (see Bennet 1992).

In the 2000s, Egyptian legislation on international trade has become more flexible, but traders still seek ways to elude the law to maximize their profits. When Port Saïd lost its last attributes as a duty-free zone in 2002, the importers of Cairo and Alexandria got around quotas and taxes by delivering part of their goods to the closest low-tax container ports outside Egypt, such as those in Libya. These days, Chinese jeans or global gadgets sold on the Egyptian market often arrive from the Libyan ports of Tripoli and Benghazi by road, passing through the border village of Salloum, as I will now explore ${ }^{2} .2$

\section{Salloum: a Bedouin village and border warehouse}

Twelve hours by road west of the Egyptian capital city is the Egyptian village of Salloum, on the Libyan border, where an intense movement of people and goods takes place. Egyptian emigration to Libya is a well-known phenomenon, which is both long-standing - it started at the beginning of the 1970s - and massive: officially 300,000 Egyptian migrants work in Libya (Zohry 2003). However, it is not the traffic of people which strikes the visitor to Salloum but the traffic of goods: not only Chinese blue jeans, but also all kinds of small products subject to quotas and/or customs duties in Egypt. Salloum, despite its apparent remoteness, is an essential link in the transnational route supplying Egypt from China via Dubai and Libya.

The profession of smuggler emerged from this informal but necessary tolerance at the border. On the Egyptian side, smuggling is openly practiced and considered an ordinary job by the actors in the border trade. They work at the request of the Egyptian forwarding agents who come to Salloum to take delivery of the goods that their Libyan counterparts send from Tripoli to the border. Smuggling usually means carrying loads of blue jeans or other goods (denim jeans from China were the main product smuggled into Egypt while I did field research in Salloum, but different types of small commodities and garments transit there according to opportunities and demand), walking from one side of the border to the other. The smugglers circumvent the Egyptian frontier post, pass through the Libyan customs check-point, and go into the Libyan village of Msaïd, and then make their way back with the goods they have picked up, always depending on the fluctuating tolerance of the customs officers. Once in Egypt, they load the goods into covered taxis commuting between the border and the warehouses on the main street of Salloum, ten kilometers away.

Smuggling is a banal activity here. For the porters and the conveyors, it does not represent something isolated and illegal but rather serves as an essential link in the importation of goods into Egypt. The blue jeans pass from the Libyan exporters' hands to those of their importing counterparts on the other side of the border; the rest of the business boils down to logistics depending on the conditions of the road. The smugglers may be men or women, Bedouins native to the Salloum region or Egyptians. Some of them came here after a first experience in smuggling in Port Saï; others explain that they came because they "had heard of Salloum," preferring to work here than to emigrate to Libya or the Gulf countries to make a living. Most live in this border village so that they can work in different jobs relying on the border trade: as carriers of goods or drivers, but also money-changers or workers in the services that Salloum offers to residents, migrants or travelers.

The commercial facilities of the locality reflect its two main functions: storage of goods and hospitality for those who make their living from these goods as well as those who stop in the village for just a few hours. The center of Salloum, along the main road, is very busy, especially early in the morning when the different players in the border trade take their breakfast before going up the hill to the frontier point, and after sunset, when everybody meets again downtown. Salloum's main street features about 230 businesses in a 900-meter stretch: coffeehouses, restaurants, phone shops, and shops of imported products as well as warehouses. There are also seven hotels to accommodate travelers, customs officers and security forces.

\footnotetext{
2 According to my investigations in Salloum in 2006, cotton denim blue jeans made in China were bought by peddlers at the Libyan border at about EGP20-25 (one US dollar was worth EGP3.5) and then sold in the seaside resort of Marsa Matrouh at EGP40-45, and in the metropolises of Alexandria and Cairo at EGP50-60.
} 
Salloum's Bedouins are well entrenched in the border commercial chain, either as carriers of the parcels of blue jeans, or if they have enough money, as speculators on the sale or rent of warehouses on the other side of the border. The warehouses are simple rooms of ten meters square made up of racks and a front counter where the smugglers place their loads and the purchasers negotiate with them. Those goods generally do not remain on display for long, as Ahmed, one of the forwarding agents for Chinese jeans, who has been commuting between Cairo and Tripoli for twenty years, explained to me. Ahmed goes to the Libyan capital twice a month, and negotiates directly with the Libyan wholesalers who deliver cargo worth several thousand euros to the border. Then he picks up his order in Salloum and takes it to the wholesalers of Alexandria and Cairo, who sell the goods on the Egyptian market.

\section{The trading post of Tripoli}

Situated 20 hours west of Salloum by road, Tripoli has been returning to its historical role as a Mediterranean port and transnational commercial center due to its low import taxes and its location at the crossroads of migratory and trade flows between the Sahel (Sudan, Chad and Niger) and North Africa (Tunisia, Algeria and Egypt).

The wealthy state of Libya, with its interventionist economic policy, controlled the national market by subsidizing the import of many consumer goods from the 1970s until the oil price counter-shock of the mid-1980s. During that period, the difference between the prices charged in Libya and those charged in neighboring states was so significant that smuggling networks were set up to export the subsidized goods illegally and sell them overseas (Boubakri 2000). The drop in oil prices in the mid-1980s and the embargoes on Libya (1982-1999) largely ended this economic activity and caused a drop in the national currency, the Libyan dinar. In just a few years, after public authorities reduced subsidies and low taxation was introduced, the players in the illegal re-exportation of goods from Libya turned Tripoli into a market for the re-exportation of imported goods from Asian markets (Pliez, 2004).

Today, hundreds of Libyan wholesalers and importers connected to Istanbul, Dubai and the East Asian industrial districts trade with North African, African and Egyptian re-exporters who oversee the supply of commercial chains several thousands of kilometers long. They have turned the central districts of Tripoli around the harbor into a vast storage area for markets, which are often ethnically oriented (such as the African market, the Chadian street, and the Rachid street area), stockrooms, and wholesale shops. Mid-range hotels accommodating foreign dealers and shopping malls attracting the shoppers of the capital have grown in number.

The old city of Tripoli and its surroundings have become an employment site for hundreds of sub-Saharan, North African and Middle Eastern migrants at the lower levels of this transnational commercial chain, those who moved to Libya during the 1990s embargo (Bredeloup and Zongo 2005; Pliez 2006). They carry parcels, sew garments, or negotiate imported goods with wholesalers from Libya's neighboring countries - although of course all this has been changing with the Libyan revolution of 2011, whose ultimate outcomes remain to be seen.

\section{Yiwu: a Chinese supermarket of the Arab world}

Of course, life has improved. We couldn't have imagined any of this ten years

ago. This small town with mud houses now has an airport, a world trade

center, skyscrapers, hundreds of factories, hotels, and two Middle Eastern

restaurants with belly dancers. We hardly had any schooling, but our daughter

studies marketing at college.

Jin Xiaoqin, owner of Yiwu Toys (Wang 2005)

"Build the largest supermarket in the world. Build an international shopping paradise." The slogans on the walls of the main hall of the annual International Fair in Yiwu are not the incantation of some municipal officials in a small and isolated village of rural China, but the expression of the success of this "Made in China" showcase. Yiwu is indeed one of the central commercial centers in China, a world-scale low-price wholesale showroom specialized in the sale of "small commodities," i.e. small household goods, jewelry, razors, toys, and religious artifacts.

The easiest way to describe the market of Zhejiang, two hours away by train south of Shanghai, is to list its superlatives: the surface area of the markets exceeds 2.5 million square kilometers; 58,000 shops offer 400,000 different goods; and 80 trade fairs take place each year, the most important being the annual international fair 
which attracts 16,000 foreign visitors over three days. Yiwu is probably unique both for its scale and for the diversity of its products. However, despite the operators I met in this market who praise Yiwu as the "capital of small commodities," it remains primarily a textile area, with a third of its export sales clothing, 12 percent socks and 7 percent various other textiles (Yiwu Industry and Commerce Administrative Bureau 2006). The growing number of transnational buyers, who sometimes come with little money, is made possible by the fact that in Yiwu they can fill up a container with different types of product instead of only one product, as is often the case in other East Asian markets. Yiwu is known as a major center of copied goods in China, with about 80-90 percent of all goods offered for sale being counterfeit or goods infringing copyright (Chow 2003). Its prices are at the moment unbeatable. For all these reasons, in Yiwu one can find more products than anywhere else and a multitude of people from around the world can test their fortunes in small-scale transnational trade.

The International Trade Center (ITC), with a total of 17,000 shops, has provided an accessible center for Yiwu's specialized markets one year after China joined the WTO; three fourths of the commercial transactions carried out in the city are concentrated here. In 2008, the Yiwu market was divided into 5 markets (Binwang, ITC I, II, III, IV) and specialized streets bringing together a total of 620,000 booths of Chinese suppliers (Zhejiang China Small Commodities City Group 2009). It is at the heart of Yiwu's emergence as one of the world's major sources of the goods that fuel globalization from below.

In the 1970's, Yiwu was one of many small industrial cities in China, each of which specialized in the production of small commodities in accordance with the economic doctrine of that time: "one village, one product." But the economic liberalization led by Deng Xiaoping in the 1980's brought competition between these mono-specialized localities to attract Chinese customers in a competitive production market. In this context, driven by local trade operators with the support of public authorities (Chow 2003), Yiwu gradually became a local and then a regional trading city of the specialized mono-industries dispersed in the Zhejiang countryside (Ding 2007). A new stage was reached in the 1990s, when the operators who ran Yiwu's markets went into partnerships with private commercial operators located in other Chinese provinces. Together they created a network of markets to sell the goods produced around Yiwu: today, about fifty markets in twenty-five Chinese provinces are connected to the market of Yiwu (Sun and Martin 2008). They are usually located in the main cities of each province, and can be found in border provinces and in ports connected to South Korea or Japan. In 2001, the People's Republic of China joined the World Trade Organization and attracted transnational trade operators that had dealt with Southeast Asian markets until the financial crisis of 1997. Today, two thirds of the sales in Yiwu are within a huge world market.

Exports from the RPC to the Arab world have grown significantly with the increasing demand for consumer goods caused by the explosion of oil prices (Habibi 2006). Therefore, a trading outlet of major importance for the exports of Yiwu has opened towards the vast consumer market of the Middle Eastern and North African region looking for inexpensive products. In 2005, China ranked among the four principal exporting partners of nine of the 19 countries of the MENA region, ranking first in Sudan and UAE and second in Iran and Jordan. However, this increasing presence of Chinese imports in terms of volume is most striking in two states, namely Saudi Arabia, where China's market share doubled (from 3.6 to 7.2 percent) between 2000 and 2005 and the United Arab Emirates, where it made a 320 percent jump during the same period (Habibi 2006).

There is a trade history linking Yiwu and Dubai, which was long the main trading interface between the Arab world and China. However, during the 2000s, many purchasers have come alone or in small collectives directly to Yiwu, circumventing Dubai, in order to find the lowest prices. They usually walk around in tandem with their interpreter, most often a young multilingual Chinese intermediary, and deal directly on site, having been provided with the names and addresses of their potential suppliers and of the districts where they will stay. Most of the Arab tradesmen report similar routes which led them to add China to their transnational trading destinations during the 2000s, after southern Europe in the 1980s and Turkey, the United Arab Emirates, and Southeast Asia in the 1990s. Often, they entered China step by step, first traveling to Hong Kong to buy Chinese goods (often staying at Chungking Mansions: see Mathews' chapter 4), and then going directly into mainland China to buy.

An Egyptian stationery importer I spoke with has been traveling to China for ten years to buy small low-cost articles (pens, erasers, etc). Five years ago, the French company which was his main supplier relocated its production to Shanghai. His French partner invited him to visit the Shanghai production site and the main markets of the area. So he went to Yiwu in 2003 but "only saw souks like the ones in Cairo: articles of bad quality sold on the pavement by small craftsmen." Skeptical and disappointed, he left after placing only one small order. But after 
new talks with his French supplier and with other Egyptian importers he eventually changed his opinion: "Then I understood that Yiwu was an important trading city but that I had not understood its rules during my first visit. I needed to be guided." Today, Yiwu is his principal destination in China; he goes there every two months, each time for short stays of two to three days. He devotes this time to meeting his suppliers, and to looking at the huge showrooms of the International Trade City, and sleeps in Yiwu's new five-star hotel in the city center. "In the evening, the city is a little bit livelier than before" he says, especially in the vicinity of the "Arab district," which can be identified by the smell of kebab. This highlights one emergent feature of the city: the setting up of a hospitality structure for the foreigners who visit or live in Yiwu.

\section{Muslim hospitality}

The bonds of trade between Yiwu and Arab countries have resulted in the development of an Arab community of 3,500 residents (Al-sin al yowm: 2006) out of a total of 6,000 to 8,000 foreigners living in the city. The presence of so many Muslim tradesmen has led to the emergence of a so-called Arab district in downtown Yiwu ${ }^{3}, 3$ a place where almost everything is written in Arabic. The tradesmen meet after 5:30 pm (when the International Trade Center closes its doors) in the Algerian, Egyptian, Iraqi, and Lebanese restaurants of the area. This district solves a crucial problem for these Muslim travelers: where to find halal food, food which conforms to the precepts of Islam, especially in a country where language problems are acute and where pork and alcohol are very popular.

Yiwu's resident Muslim traders and merchants, whether they are Arab, Asian or African, attract many Chinese Muslims as a consequence of their religion (there are some 20 million indigenous Muslims in China: Gladney 1994). While Yiwu has received a large number of migrants from inside China (at least 600,000 ) who come to work in industrial workshops, the migration of Muslims is mainly from the western autonomous regions of China (Ningxia and Xinjiang), and is mostly linked to the catering needs of the city's foreign Muslim visitors. For example, the Uighurs of Xinjiang, a Turkish-speaking group from Central Asia, have earned a good reputation as animal slaughterers and mechoui cooks. They can be found in every restaurant of the district, where they butcher sheep and grill the meat on barbecues every evening. The majority of these Muslims work for the managers or owners of the Arab district restaurants. However, as the manager of an Algerian restaurant confides, "Communicating with them is not so easy: their Arabic, their English, you don't understand their accent very well." Most of the Arab residents of Yiwu have learned some Chinese in order to try to get around the language problem.

A Muslim community in Yiwu is thus being built into the meshes of the geopolitical and commercial agreements which have defined the renewal of relations between the African and Asian continental blocks during the 2000s. Global networks can materialize in seemingly improbable places such as the previously mentioned "Arab district" in Yiwu, where Arab restaurant owners employ Chinese Muslims to cater for the busy traders, providing them with a place to negotiate and relax, a place where they can build ties with a degree of confidence. They share the same goal: to make money rapidly. They also share the same religious identity, that of Islam.

I consider the "Arab street" of Yiwu as an exemplary site of transnational commercial exchange networks from below. Ethnic enclaves have multiplied near supply sources located in the world's Asian factories. This is the case in Beijing (Gladney 1994), in Guangzhou (Bertoncello and Bredeloup 2007) and in Bangkok (Marchal 2007; Simone 2007). "The Muslim Street is Everywhere," suggested Abdoul Maliq Simone in describing the district of Soi Sukhumvit 3 in the Thai capital, which "anchors the

intersection of Arabs and Africans from all over the world" (2007: 593). This is as relevant in Yiwu as in Bangkok. Today the secular links between Muslim worlds not only transcend states but also post-colonial northsouth and center-periphery relationships, to provide coherence to the globalization of cultural, religious and commercial exchanges (Dennerlein and Reetz 2007).

However, we cannot essentialize these interactions, because these enclaves are just one among many practical ways to make the global traffic flow more fluid. In the "Arab street" of Yiwu, the Arab restaurant owners and their Muslim Chinese employees cater to traders in a hurry; they also provide them with places of exchange and connectivity (Kesselring 2006). Is it any different in the harbor district of Tripoli or in the main street of Salloum, where traders, migrants and occasional guests meet? Is it any different in Yiwu itself, where the Muslim enclave

\footnotetext{
3 I found different names for this area: san mao chu ("economic quarter no 3") is the former administrative name, recently renamed "Exotic Street"; Chinese native speakers call it maedah (table in arabic) in reference to the first Arabic restaurant built in Yiwu; Arabic native speakers usually call it the Arab street, Arab restaurant (alabo fan dian in Chinese), or Maedah.
} 
is next to the African, Russian, Hispanic, and Korean enclaves? Streets such as these bring people together for specific reasons, such as the language or the food (such as the importance of halal food for Muslims), but that might not be enough to explain the multiplication of "Muslim streets." Moreover, the Arab street of Yiwu attracts as many Chinese people, who come to discover the culinary tastes of the Middle East, as it does foreign Muslims who spend a few days in the city.

\section{Conclusion: the uncharted geography of transnational networks}

Following the "new silk road" between China and Egypt and therefore emphasizing the links between these places is a methodological and heuristic means for anthropologists, geographers and other social scientists to understand the focal sites of transnational networks. It enables us to put their characteristic commercial enclaves into perspective on a global scale, and also reminds us of the fact that these networks are not created spontaneously, but from layers of economic and social circumstances.

This is the case not only at present, but also for the maritime trading posts of the ancient Mediterranean, the medieval silk roads, and the Trans-Saharan caravan roads which reached their height in the nineteenth century, and the foreign concessions of coastal China during the first decades of the twentieth century.

It is necessary to locate these on their own geographical scale. They are, as in the Xiaobei neighborhood of Guangzhou (see Yang's chapter 9), "a combined result of both so-called 'globalization from below' and a locality such as Guangzhou's commercial culture, religious traditions and trading networks" (Li, et al. 2007). They also should be located on a global market timescale: over the last twenty years, Arab migratory and trade routes have undergone radical changes. Until the 1980s, Arab merchants were in the port cities of Southern Europe (Peraldi 2005). During the 1990s, Arab merchants plied their trade in Turkey and the Gulf States. From there, they entered Southeast Asia step by step until the financial crisis of 1997 and the entry of China into the World Trade Organization in 2001. The 2000s represent the beginning of the Chinese phase of the globalization of these Arab routes.

And finally we must define these networks by their local contexts. The size of the Egyptian consumer market for low-price products, the fringe society of the Bedouin populations at the border between Egypt and Libya, the Libyan economy, founded both on oil and gas revenue and on an economic laissez-faire policy during the embargo of Libya (1982-1999), the involvement of both public and private local social actors in Yiwu, in the heart of one of the main Chinese "world factory" provinces, Zhejiang-all these factors are essential to the formation of focal sites of economic globalization from below along the global road from Cairo to Yiwu. Economic globalization from below in commercial exchanges creates new scales of observation for their discontinuous but strongly interconnected units of space. They are located at the intersection of migratory, production and circulation areas, which are older and often distinctive, such as the Egyptian-Libyan migratory system. They involve a growing number of both local and transnational players.

The making of these places involve many uncertainties. Price competition, for example, can be limited by consumers' search for better quality products. The consequence is that tough competition triggers the development of trading posts located in production areas. All these sites are linked along global trade routes on the condition of a constant renewal of the efforts by the commercial players who enliven these hubs. They must maintain low prices from the production sites to the retail sale of the goods. They must ensure good conditions of hospitality for the traders. And they must deal with many legal constraints, such as protectionist barriers, borders, national and international legislations or the reversals of the world economic situation (AFP Asian Edition 2009).

The success and sustainability of the routes of globalization from below often vary according to the places they go through. The commercial enclaves are numerous and varied along the multiple roads that bind the continental blocks of Africa and Asia.

They are commonly presented by the media and politicians as explanatory factors of the new geopolitical and commercial world. One does not talk business from continent to continent or from country to country, but from place to place: places to buy (Yiwu), places to sell either to local wholesale dealers or to private individuals (Cairo), places to take delivery and to re-forward (Tripoli), and sometimes also places to divert goods (Salloum). Each of these places could be intensively studied, following spatial but also anthropological perspectives. The logic of the actors who follow the global routes, whether importers, smugglers or migrants, and the logic of local actors, whether they accommodate (money changers, cooks), deal (peddlers, wholesalers, translators, traders), or 
manage (municipalities, boards of trade) are constantly embedded within the particularities of these places.

The connection between such places seems at first glance unlikely. It is the temporary result of social and spatial networks meshing in the 1990s and 2000s. What of today? After the bankruptcy of Dubaï in 2009, the Arab revolts of 2011 may be followed by profound changes along the transnational roads between China and the Arab world. In the course of those revolts, Cairo became the symbol of the aspirations of freedom of the Arab populations, Tripoli was a battlefield, and Sallum hosted refugees during the Libyan civil war. But this new geopolitical situation won't necessarily lead to the end of the new Silk Road. Transnational trade networks often lead to a dynamic constituting or reconstituting of places within changing territorial configurations, and new networks of trade may emerge. Whatever may come, it seems clear that understanding the connections explored in this chapter can serve to clarify the inconspicuous geography of the nodes and networks which link the world. They are a necessary complement to the metaphor of fluidity which is so often used to describe the flows of people and goods across the globe - a metaphor which is accurate, but which nonetheless tells only part of the story, the other part of which I have tried to tell here.

\section{References}

AFP Asian Edition (2009) "Global Crisis hits China's Huge Yiwu Market, but Optimism Remains," http://www.thefreelibrary.com/Global+crisis+hits+China's+huge+Yiwu+market,+but+optimism+remainsa01611783822 (accessed October 14, 2011).

Al-sin al yowm (2006) http://www.chinatoday.com.cn/Arabic/2006n/0612/index.htm (accessed October 14, 2011).

Appadurai, A. (2000) "Grassroots Globalization and the Research Imagination," Public Culture 12(1): 1-19.

Bennet J. (1992) “Chinese Agency Indicted in Jeans Import Scheme,” New York Times, October, 6.

Bertoncello, B. and S. Bredeloup (2007) "The Emergence of New African 'Trading Posts' in Hong Kong and Guangzhou," China Perspective 218: 94-105.

Boubakri, H. (2000) "Echanges transfrontaliers et commerce parallèle aux frontières Tuniso-Libyennes" [TransBorder Exchanges and Informal Trade through the Tunisia-Libya Border], Monde Arabe, Maghreb Machrek, La Documentation Française 170: 39-51.

Bredeloup, S. and M. Zongo (2005) "Quand les frères burkinabè de la petite Jamahiriyya s'arrêtent à Tripoli" [When the Burkinabè Brothers of the "Small Jamahiriyya" Stop in Tripoli], Migrations entre les deux rives du Sahara, Armand Colin-IRD 36: 123-47.

Broadman H. (2007) Africa's Silk Road: China and India's New Economic Frontier, Washington DC: World Bank Publications.

Bruyas, F. (2007) "Méga-projets' nationaux et dynamiques identitaires locales: Le cas de Port-Saïd et des autres villes du Canal de Suez" [National 'Mega-Projects' and Dynamics of Local Identity: The Case of Port Said and other Cities of the Suez Canal], É. Denis (ed.), Villes et urbanisation des provinces égyptiennes. Vers l'écoumènopolis? Paris/Le Caire, Karthala/Cedej.

Burawoy, M. (2003) "Revisits: An Outline of a Theory of Reflexive Ethnography," American Sociological Review 68(5): 645-79.

Chow, D. (2003) "Organized Crime, Local Protectionism, and the Trade in Counterfeit Goods in China," China Economic Review 14(4): 473-84.

De Coster, J. (2006) “New Egyptian Consumers Want China Retail Prices.” International Market News, 12 May.

Dennerlein, B. and D. Reetz . (2007) "Continuity and Disparity: South-South Linkages in the Muslim World," Comparative Studies of South Asia, Africa and the Middle East 27(1): 3-6.

Ding, K. (2007), "Domestic Market-based Industrial Cluster Development in Modern China," Discussion Papers no.88, IDE-JETRO, Tokyo, http://www.ide.go.jp/English/ Publish/Dp/pdf/088_ding.pdf (accessed October 14, 2011). 
Gladney, D. (1994) "Sino-Middle Eastern Perspectives Since the Gulf War: Views from Below," International Journal of Middle East Studies 29(4): 677-691.

Habibi, N. (2006) "China builds Growing Middle East Export Market Share, at the Expense of Competitors," AlJazeera,

http://www.aljazeerah.info/Opinion\%20editorials/2006\%20Opinion\%20Editorials/May/31\%20o/China\%20Builds $\% 20$ Growing\%20Middle $\% 20$ East $\% 20$ Export $\% 20$ Market $\% 20$ Share, $\% 20 \mathrm{At} \% 20$ the $\% 20$ Expense $\% 20$ of $\% 20$ Compe titors\%20By

\%20Nader\%20Habibi.htm (accessed October 14, 2011).

Kesselring. S. (2006) "Pioneering Mobilities: New Patterns of Movement and Motility in a Mobile World," Environment and Planning A 38(2): 269-79.

Li, Z., D. Xue, M. Lyons, and A. Brown (2007) "Ethnic Enclave of Transnational Migrants in Guangzhou: A Case Study of Xiaobei," Conference on China's Urban Land and Housing in the 21st Century, Hong Kong, December 13-15, 2007, http://www.hkbu.

edu.hk/ curs/Abstracts\%20and\%20Fullpapers/05/07.doc (accessed October 14, 2011).

Marchal, R. (2007) "Hôtel Bangkok-Sahara," [The Bangkok-Sahara Hotel], in F. Adelkhah and J. F. Bayart (eds), Voyages du Développement: Emigration, Commerce, Exil, Paris: Karthala, Coll. Recherches internationales.

Marcus, G. (1995) "Ethnography In/Of the World System: the Emergence of Multi-Sited Ethnography," Annual Review of Anthropology 24: 95-117.

Molavi, A. (2007) “The New Silk Road,” Washington Post, April, 9.

Peraldi, M. (2005) "Algerian Routes: Emancipation, Deterritorialisation and Transnationalism through Suitcase Trade," History and Anthropology 16: 47-61.

Pliez, O. (2004) "De l'immigration au transit? La Libye, dans l'espace migratoire euro-africain" [From Immigration to Transit? Libya in the Euro-African Migratory Space], La nouvelle Libye, géopolitique, espaces et sociétés au lendemain de l'embargo, Paris: Karthala, 139-57.

- (2006) “Tripoli, vers l'effacement de l'africanité de la capitale libyenne?" [Tripoli: Towards the Blurring of the African Identity of the Libyan Capital?], Migrations Société 18(107).

- (2007) "Des jeans chinois dans les rues du Caire, ou les espaces discrets de la mondialisation" [Chinese Jeans on the Streets of Cairo: A Stroll Through the Discreet Places of Bottom-up Globalization], Mappemonde 88, http://mappemonde.mgm.fr/num16/articles/ res07404.html (accessed October 14, 2011).

Ribeiro, G. (2009) "Non-hegemonic Globalizations: Alter-native Transnational Processes and Agents," Anthropological Theory 9: 1-33.

Simone, A. (2007) "The Muslim Street is Everywhere (and soon coming to a theater near you)", Geoforum 38(4): 593-96.

Simpfendorfer, B. (2009) The New Silk Road: How a Rising Arab World is Turning Away from the West and Rediscovering China, New York: Palgrave Macmillan.

Stuttard, J. (2000) The New Silk Road: Secrets of Business Success in China Today, New York: John Wiley \& Sons.

Sun, Z. and P. Martin (2008) "The Role of Trading Cities in the Development of Chinese Business Clusters," International Business Research 1(2): 69-81, http://ccsenet.org/journal/index.php/ibr/article/viewFile/993/969 (accessed October 14, 2011).

Trade Egypt (2010) http://trade.ec.europa.eu/doclib/html/113375.htm (accessed October 14, 2011).

Wang, P. (2005) “Three Poems,” Manoa 17(1): 106-11.

Yiwu Industry and Commerce Administrative Bureau. (2006) Complete Commercial Guide to China Commodity City - Yiwu, China, vol.1, Peking: China Youth Press.

Zakaria, E. (2006) "Role of Urban Greenway Systems in Planning Residential Communities: A Case Study from 
Egypt,” Landscape and Urban Planning 76(1-4): 192-209.

Zhejiang China Small Commodities City Group (2009) http://www.onccc.com (accessed October 14, 2011).

Zohry, A. (2003) "The Place of Egypt in the Regional Migration System as a Receiving Country," Revue Européenne des Migrations Internationales 19(3), http://remi.revues.org/index2664.html (accessed September 7, 2009). 